\title{
Fitopatojenlere Karşı Dayanıklılıkta CRISPR/Cas Teknolojisi
}

\author{
Serap Demirel ${ }^{1 *}$, Mustafa Usta ${ }^{2}$, Fatih Demirel ${ }^{3}$ \\ 1*Van Yüzüncü Y1l Üniversitesi, Fen Fakültesi, Moleküler Biyoloji ve Genetik Bölümü, Van, Türkiye, (ORCID: 0000-0002-3102-4924), serap_comart@hotmail.com \\ ${ }^{2}$ Van Yüzüncü Yıl Üniversitesi, Ziraat Fakültesi, Bitki Koruma Bölümü, Van, Türkiye (ORCID: 0000-0002-3940-2774), mustafausta@yyu.edu.tr \\ ${ }^{3}$ Iğdır Üniversitesi, Ziraat Fakültesi, Tarla Bitkileri Bölümü, Iğdır, Türkiye (ORCID: 0000-0002-6846-8422), drfdemirel@gmail.com
}

(İlk Geliş Tarihi 7 Temmuz 2020 ve Kabul Tarihi 4 Kasım 2020)

(DOI: 10.31590 /ejosat.765369)

ATIF/REFERENCE: Demirel, S., Usta, M. \& Demirel, F. (2020). Fitopatojenlere Karşı Dayanıklılıkta CRISPR/Cas Teknolojisi. Avrupa Bilim ve Teknoloji Dergisi, (20), 693-702.

$\ddot{\mathbf{O} z}$

Tarım ürünlerinde hem hücre içi hem hücre dışı bitki patojenleri dünya çapında ekonomik olarak önemli kayıplara neden olmaktadır. Genom düzenleme teknolojileri özellikle de CRISPR/cas sistemi, tarım ürünlerinde gerek kalite gerekse verimin iyileştirilmesi amacıyla son zamanlarda farklı alanlarda kullanılmıştır. Bakteri, arkea, faj ve yabancı plazmitlere karşı savunma sağlayan CRISPR/cas sistemi tarımsal özelliklerin araştırılması ve düzenlenmesi için eşsiz firsatlar sunan bir araçtır. Bu derlemede hastalıklara neden olan fitopatojenlere karşı mücadelede CRSPR/cas sisteminin kullanım etkinliği irdelenmiştir. Ayrıca CRISPR/cas sistemi aracılığıyla fungus, bakteri ve virüslere karşı konukçu bitkide dayanıklılık ve duyarlılıkta rol oynayan genlerin modifikasyonlarının mevcut durumu ortaya konmuştur. Çalışmalar, CRISPR/cas sisteminin bitkilerde fitopatojenlere karşı dayanıklılık sağlamada etkili olduğunu ortaya koymuştur. Genom düzenleme alanındaki ilerlemeler ve CRISPR/cas ile transgen içermeyen bitkilerin elde edilmesi gelecekte bitki patolojisinde yeni hastalık yönetim ve mücadele stratejilerinin geliştirilmesine olanak sağlayabilecektir. Ayrıca gelecekte CRISPR/cas genom düzenleme teknolojisi ile birden fazla patojene eş zamanlı olarak dayanıklı bitkilerin geliştirilmesi de mümkün olabilecektir.

Anahtar Kelimeler: CRISPR, Genom Düzenleme, Fitopatojenler, Bitki Islahı, Sürdürülebilir Tarım.

\section{CRISPR/Cas Technology in Resistance to Phytopathogens}

\begin{abstract}
The intracellular and extracellular plant pathogens cause economically significant loss to agricultural products worldwide. Genome editing technologies, especially the CRISPR/cas system, have recently been used in different fields in order to improve both quality and yield in agricultural products. The CRISPR/cas system which provides defense in microorganisms against bacteria, archaea, phage and foreign plasmids is a tool that offers unique opportunities for research and regulation of agricultural properties. In this review, the effectiveness of the CRSPR/cas system in the fight against phyto-pathogens causing diseases was discussed. In addition, the current status of modifications through the CRISPR/cas system of genes that play a role in resistance and susceptibility to the host plant against fungi, bacteria and viruses was revealed. The CRISPR/cas system has been shown to be effective in providing resistance to phytopathogens that have destructive effects on plants. Advances in genome editing and the production of transgene-free plants with CRISPR/Cas will enable the development of new disease management and control strategies in plant pathology. In the future, it will be possible to develop resistant plants to more than one pathogen simultaneously with CRISPR/cas genome editing technology.
\end{abstract}

Keywords: CRISPR, Genome Editing, Phyto-Pathogens, Plant Breeding, Sustainable Agriculture.

\footnotetext{
*Sorumlu Yazar: serap_comart@hotmail.com
} 


\section{Giriş}

Küresel popülasyonun sürekli olarak artmasından dolayı günümüz problemlerinden biri gelecek nesillerin ihtiyaç duyacağ1 besin kaynaklarının yetersizliğidir. $\mathrm{Bu}$ talebi karşılamak için 2005-2050 yılları arasında besin üretiminin \%100 ile \%110 arttırılması gerekmektedir (Tilman ve ark., 2011). Bitkiler yaşamları boyunca farklı abiyotik ve biyotik stres faktörlerinden etkilenmektedir (Zaidi ve ark., 2016). Bu stres faktörleri fiziksel, biyokimyasal ve moleküler düzeyde bitkileri etkileyerek çoğunlukla verim ve kalitede azalış, büyüme ve gelişmede anormallikler, bitki fizyolojisinde bozulma gibi olumsuz etkilere neden olmaktadırlar. Dolayısıyla bitkileri abiyotik ve biyotik stres faktörlerinden korumak ya da onları strese karşı dayanıklı kılmak sürdürülebilir tarım adına büyük önem taşımaktadır. Bitkilerin hastalıklara karşı dayanaklığının arttırılması sürekli olarak artan insan nüfusunun besin ihtiyacını karşılamak adına önem taşımaktadır (FAO, 2017). Dayanıklı çeşitler kullanarak hastalığı kontrol etme yaklaşımı genellikle tarımda kullanışı bir yöntemdir. Ancak çoğu bitki patojeninin yüksek evrimsel potansiyele sahip olmasından dolayı bitkilerde mevcut olan dayanıklılığın kırılması her zaman muhtemeldir. Rekombinasyon ya da mutasyon gibi farklı mekanizmalar ile ortaya çıkan yeni patojen 1rkı, dayanıklı bitkilerde hastalık dayanıklılığını kırdığında, doğal seleksiyon aracılığıyla yeni genotipin frekansının artması ve hızlı bir şekilde diğer lokasyonlara yayılması nedeniyle mevcut hastalık yönetim stratejileri hızlı bir şekilde etkisiz hale gelebilmektedir (Borrelli ve ark., 2018). Bitkilerde genetik varyasyon oluşturmak, sürdürülebilir tarımın ve hastalık yönetim stratejilerinin esaslarından biridir (Griggs ve ark., 2014). Geleneksel 1slah programı bitkilere dayanıklılık sağlayan doğal ya da uyarılmış allellerin belirlenmesi ve bu allellerin farklı sslah teknikleri ile üstün genotiplere aktarılmasına dayalıdır. Mutasyon ıslahı ve geleneksel 1slah yöntemleri patojenlere karşı dayanaklılığı arttırmak için geniş ölçüde bitkilerde uygulanmıştır. Mutasyon ıslahı ile oluşturulan birçok bitki, çeşitli hastalıklara karşı dayanıklılık göstermiştir (Miklis ve ark., 2007; Christopoulou ve ark., 2015). Geleneksel 1slah yaklaşımının etkinliği mevcut fonksiyonel çeşitliliğe bağlıdır. Bu çeşitlilik kültüre alma süresince ortaya çıkan genetik darboğaz nedeniyle sınırlı kalmaktdır (Shi ve ark., 2015). Doğal ya da rastgele uyarılma sonucunda elde edilen çeşitlilik, ıslah sürecinde sinırlayıcı faktörlerdendir ve bitki sslahında tahmin edilemeyen sonuçlara neden olmaktadır (Watson ve ark., 2018; Scheben ve ark., 2018). Gelişen teknoloji ile birlikte birçok bitkinin genom ve transkriptom sekanslarının mevcut olması bitki 1slahında yeni bir dönem başlatmıştır (Borrelli ve ark., 2018). Biyoteknolojideki hızlı gelişmeler bitki ıslahına farklı bir boyut kazandırmıştır. Genom düzenleme tekniği son zamanlarda bitki ıslahında popüler olan biyoteknolojik yaklaşımlardan biridir. Genom düzenleme, dizi spesifik nükleazların kullanılarak herhangi bir organizmanın genomunda istenilen DNA dizisinde çıkarma, ekleme ya da parça değişimi şeklinde değişimler meydana getirme olayıdır (Dunn ve Pinkert, 2014). Genom düzenleme, genomik lokusta tam, etkili ve hedef modifikasyanlara imkan sağlayan ileri moleküler biyoloji tekniklerini içeren bir uygulama alanıdır (Gao ve ark., 2015). Genom düzenleme teknolojisinin bitki sslahında kullanımı ile çaprazlama ve rekombinasyondan kaynaklanacak potansiyel zararlı allel oluşumundan kaçınılmakta ve doğrudan genotiplerin iyileştirilmesi mümkün olmaktadır (Zhang ve ark., 2014).

Geleneksel ıslahta genetik çeşitlilik sağlamak için kullanılan tekniklerden biri de gamma ışını aracılığıyla DNA'da çift iplik e-ISSN: 2148-2683 kırığının (DNA double-strand break=DBS) oluşturulmasıdır. Bu çift iplik kırığının onarımı DNA hasar onarım mekanizmaları ile gerçekleştirilmektedir (Puchta, 2005). Bu mekanizmanın gerçekleşmesi esnasında delesyon ve insersiyon gibi mutasyonlar 1slah popülasyonunda önceden var olmayan yeni allellerin oluşumuna neden olmaktadır. $\mathrm{Bu}$ yeni alleller bitkilerin iyileştirilmesi için bitki ıslahı ile üstün genotiplere aktarılabilir (Pacher ve Puchta, 2016). Transgenik yaklaşımlar ile akraba olmayan türlerden dahi arzu edilen özelliklerin üstün genotiplere aktarılması mümkün olmuştur. Ancak hem geleneksel mutasyon 1slahı hem de transgenik yaklaşımlar çoğunlukla rastgele DNA dizisinde mutasyon ve gen insersiyonuna neden olmaktadır. Ayrıca bu teknikler ile arzu edilen bir modifikasyondan çok daha fazlası oluşabilmektedir (Herrera-Estrella ve ark., 1983; Klein ve ark., 1988). Dizi spesifik nükleazların yönlendirilmiş mutasyonda kullanılabileceğinin keşfinden sonra araştırmacılar bu nükleazlar ile genom düzenleme çalışmaları üzerine odaklanmıştır (Puchta ve ark., 1993; Salomon ve ark., 1998; Puchta ve ark., 1996). Dizi spesifik nükleazların kullanımıyla genom düzenleme, prensip olarak hedef DNA dizisinde çift iplik kırıkları (double-stranded breaks $=$ DBSs) oluşturmak ve hücre tamir mekanizmalarıyla bu kırıkların onarılması esasına dayanmaktadır. İki farklı DBS onarım yolağı tanımlanmıştır; homolog olmayan uç birleştirme (Non-Homolog End Joining-NEHJ) ve yönlendirilmiş homolog rekombinasyon (Homolog-Directed Recombination-HDR). NEHJ tamir mekanizması hataya meyilli onarım mekanizması olup çift iplik kırıkları onarılırken DNA dizisinde delesyon ve insersiyon meydana gelme olasılı̆̆ yüksektir. HDR ile DNA çift iplik onarım mekanizması donör bir DNA parçasının var olma durumunda gerçekleşmekte ve burada onarım sonrasında parça değişimi söz konusudur (Puchta, 2005) (Şekil 1). Gelişen teknoloji ile birlikte ortaya çıkan bir diğer genome düzenleme tekniği CRISPR (Clustered Regularly Interspaced Short Palindromic Repeats: düzenli aralıklar ile bölünmüş palindromik tekrar kümeleri) yöntemidir. CRISPR tekniği kolay dizayn edilebilir ve uygulanabilir olmasının yanında daha yüksek başarı oranına sahip olması ve daha ucuz maliyet gereksiniminden dolayı diğer genom düzenleme teknikliklerine oranla daha popüler bir tekniktir. Bu derlemede CRISPR genom düzenleme teknolojisinin model ve önemli tarım bitkilerinde özellikle fungus, bakteri ve virüs gibi bitki patojenlerine karşı dayanıklılık sağlamak amacıyla kullanımı irdelenmiştir.

\section{CRISPR/Cas}

Prokaryotik genomda yaygın olarak bulunan CRISPR DNA bölgesi; farklı cas proteinlerini kodlayan cas genleri, transkripsiyonun başlaması için gerekli olan öncü dizi (leading sequence), tekrar dizileri ve tekrar dizilerinin arasında yer alan "spacer" adı verilen dizilerden oluşmaktadır (Karimi ve ark., 2018). CRISPR dizileri ilk kez Ishino ve ark. (1897) tarafindan, E. coli'de egzotik tekrar dizileri olarak keşfedilmiş ve o dönemde bu dizilerin ne işe yaradığ merak konusu olmuştur. Jansen ve ark. (2002), bu dizileri düzenli aralıklar ile bölünmüş palindromik tekrar kümeleri anlamında CRISPR akronimi ile ifade etmişlerdir. Mojica ve ark. (2005) tarafindan tekrar dizileri arasında yer alan "spacer" adı verilen dizilerin, yabancı bir genomdan köken aldığı ortaya çıkarılmıştır. Barrangou ve ark. (2007), CRISPR/cas sisteminin prokaryotlarda virüslere karşı savunmada rol oynadığını ve bu sistem sayesinde bakterinin, immün sistemine benzer bir tarzda bakteriyofaj gibi yabancı organizmanın genomik saldırılarından kendini koruduğunu deneysel olarak kanıtlamıştır. Bakterilerde CRISPR savunma sisteminin 3 ana aşaması 
bulunmaktadır. Bunlar; adaptasyon, ekspresyon ve saldırganın tanınıp yok edilmesi aşamalarından oluşmaktadır. Adaptasyon, bakteri hücre içerisine giren viral nükleik asit dizisinin bakteri genomunda yer alan CRISPR adı verilen DNA bölgesine yerleştirilmesi aşamasıdır. Ekspresyon aşaması, CRISPR lokusunun transkripsiyonu sonucunda öncül bir crRNA oluşturulması ve bu crRNA'ların cas proteinleri aracılığıyla işlenerek olgun bir crRNA molekülü oluşturulması süreçlerini kapsamaktadır. Savunmanın son aşaması saldırganın tanınınıp yok edilmesi aşamasıdır. Bu aşamada crRNA molekülleri ve cas proteinleri kullanılarak yabancı genomik dizinin kesilerek parçalanması sağlanır (Horvath ve Barrangou, 2010).

Jinek ve ark. (2012) tarafından genom mühendisliği aracılığıyla oluşturulan Cas9'un genom düzenlemede kullanılabileceğinin keşfi ile birlikte 2013 yılında CRISPR/cas teknolojisi ile genom düzenleme çalışmaları hızlı bir şekilde artmaya başlamıştır. Genom mühendisliği ile oluşturulan bu nükleazlar RNA-guided engineered nucleases (RGENs) olarak isimlendirilmektedir. RGEN'ler iki bileşenden oluşan, tam bir genetik modifikasyon sağlayan sekans spesifik programlanabilir nükleazlardır (Kim ve Kim, 2014). Cas9 nükleaz ve single guide RNA (sgRNA) RGEN'lerin temel bileşenidir. sgRNA tamamlayıcı hedef diziye, cas9 nükleazı yönlendiren 5' uçta 20 nükleotite sahip bir RNA molekülüdür. gRNA'nın ilk 20 nükleotiti değiştirilerek, herhangi bir N20-NGG şeklindeki DNA sekansı genom düzenleme için hedef olarak seçilebilir ( Sander ve Jaung, 2014). 2013'ün başlarında insan genomunda genom düzenleme amacıyla CRISPR/cas teknolojisi uygulanırken, 2013 ortalarında CRISPR/cas tekniği tek bir adımda tek bir nesilde birden fazla fare geninin düzenlenmesi amacıyla kullanılmıştır (Wang ve ark., 2013). Son zamanlarda bu teknoloji biyomedikal, biyoteknoloji, kanser immunoterapi, aşı gelişimi, gen terapisi ve biyo-yakıt endüstrisi gibi birçok alanda uygulanmıştır (Dai ve ark., 2016; Lau, 2018; Javed ve ark., 2018; Bayat ve ark., 2018). Ayrıca tarım alanında kullanılan pirinç, sorgum, buğday, mısır gibi birçok bitkinin genomları farklı amaçlar doğrultusunda CRISPR/cas teknolojisi ile düzenlenmiştir (Jiang ve ark., 2013; Wang ve ark., 2014; Svitashev ve ark., 2015; Osakabe ve ark., 2016).

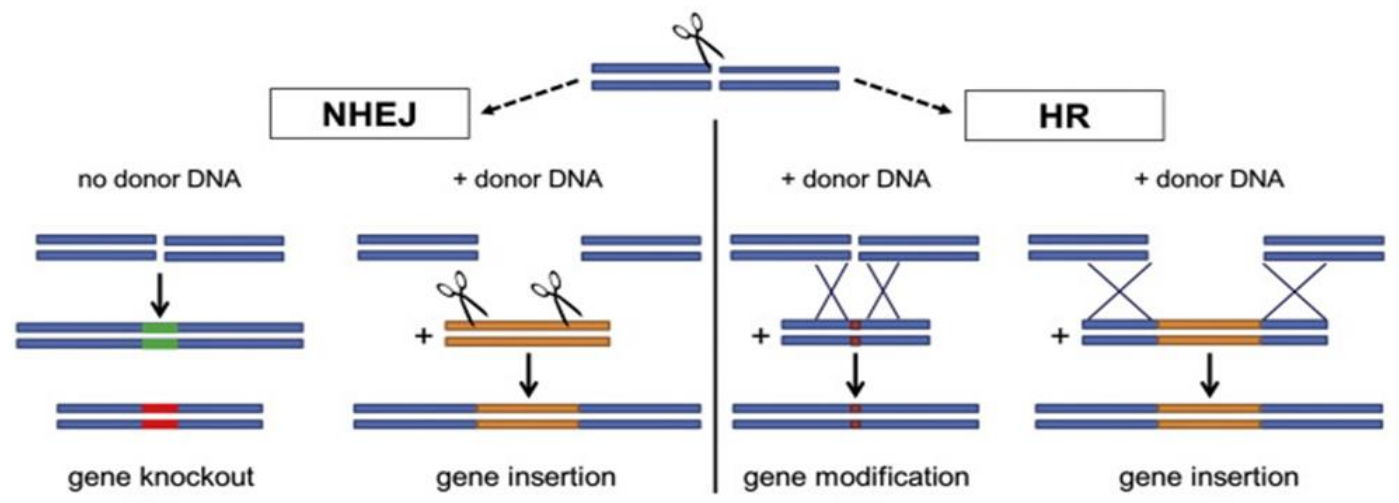

Şekil 1. Dizi spesifik nükleazlar ile genom düzenleme; çift iplik kırıkları NHEJ ya da HR aracıllı̆lyla onarılır. Onarım sonrasında ilgili genin inaktivasyonu, modifikasyonu ya da yeni bir genin insersiyonu gibi olaylar gerçekleşebilmektedir (Bortesi ve Fischer, 2015)

Genom düzenleme teknolojilerinden biri olan CRISPR/cas sistemi son zamanlarda bitkilerde çeşitli patojenlerin neden olduğu hastalıklara karşı dayanıklılık sağlamak amacıyla kullanılmış ve başarılı sonuçlar elde edilmiştir (Çizelge 1).

\subsection{CRISPR/Cas Teknolojisinin Antifungal Aktivitesi}

Fitopatojenik funguslar tarımın başlangıcından beri bitkileri tehdit eden ajanlardan biri olmuşlar ve bitkilerde kolonize olabilmek için çeşitli stratejiler geliştirmişlerdir. Bitki-fungus interaksiyonu, faydalı bir interaksiyondan konakçı bitkinin ölümüne kadar değişebilen yelpazedeki koşulları kapsamaktadır. Fungus infeksiyonları bitkilerde solgunluk, çürüklük, nekroz, ur, yapraklarda kloroz ve leke gibi farklı hastalık simptomlarına ek olarak bitki ölümüne kadar varan sonuçlara neden olmaktadır. Fungal patojenler, yüksek genetik değişikliğe sahiptir. Böylece patojenin yeni konukçu bitkilere hızlı bir şekilde yayılmasına, fungisite karşı dayanıklılık geliştirmesine ve bitki direnç geni ( $\mathrm{R}$ geni) aracılığıyla sağlanan dayanıklılığın kırılmasına neden olmaktadır (Doehlemann ve ark., 2017). Dolayisıyla fitopatojen funguslar ile mücadelede yeni stratejilerin geliştirilmesi gerekliliği araştırmacıların sürekli odak noktası haline gelmiştir. Günümüzde CRISPR/cas genom düzenleme teknolojisi sayesinde konukçu bitkide bulunan $\mathrm{R}$ ve duyarlılık genleri (S genleri) hedef alınarak funguslara karşı dayanıklılık için yeni stratejiler geliştirme çabaları popüler hale gelmiştir (Borrelli ve ark., 2018).
Funguslar tarafından çoğu bitkide görülen külleme hastalığı, yüksek derecede ekonomik kayıba neden olan, özellikle buğday başta olmak üzere birçok tarla bitkisinde tahrip edici bir fungal hastalıktır (Ateş Sönmezoğlu ve ark., 2019). Örneğin, Blumeria graminis f. sp. tritici (Bgt) buğdayda küllemeye neden olarak ürün ve verim kaybına sebep olmaktadır. Islah aracılığıyla dayanıklı bitkiler yetiştirme, külleme ile mücadelede etkili, ekonomik ve çevre dostu bir yaklaşımdır. Dayanıklılık genleri üstün genotiplere melezleme yolu ile aktarılmaktadır. Ancak bitkide dayanıklılık genlerinin çoğu, ırka spesifik olduğundan dolayı yeni ırkların ortaya çıkması külleme ile mücadeleyi zorlaştırmaktadır. Bitkilerde bulunan MLO (Mildew Locus O) genleri küllemeye karşı duyarlılık sağlamakta ve bu genlerde fonksiyon kaybının olması durumunda bitkiler geniş spektrumda fungal patojenlere dayanıklı hale gelmektedir (Piffanelli ve ark., 2004; Consonni ve ark., 2006). Arpa MLO mutantlarının keşfedilmesi, küllemeye dayanıklı bitkiler elde edilmesi için bitki 1slahında önemli adımlardan biri olmuştur (Lyngkjær ve ark., 2000). Wang ve ark. (2014), allo-hekzaploid ekmeklik buğdayda TALEN ve CRISPR teknolojilerini birlikte kullanarak küllemeye neden olan Blumeria graminis f. sp. tritici (Bgt)'ye karşı dayanıklılık sağlamışlardır. TALEN ve CRISPR teknolojisi ile TaMLO geninin bütün kopyaları eş zamanlı mutasyona uğratıldığında küllemeye karşı dayanıklı buğday bitkileri elde edilmiştir. Bu sonuçlar CRISPR teknolojisinin, farklı ploidi gösteren bitkilerde dahi genom düzenleme için uygun bir araç olduğunu göstermiştir. Oidium 
neolycopersici domateste küllemeye neden olan obligat biotrof bir fungus türüdür ve domatesin yaprak yüzeyinde beyaz lezyonlara neden olmaktadır. Fungusun şiddetli enfeksiyonlarında yaprak klorozu, meyvede olgunlaşmadan dökülme, meyve boyutu ve kalitesinde azalma görülmektedir. Domateste tanımlanan 16 Mlo geni ve bu genler arasından SlMlo1 geninin küllemeye karş1 duyarlılıkta önemli rol oynadığı belirlenmiştir (Zheng ve ark., 2016). CRISPR/cas9 teknolojisi ile iki sgRNA kullanılarak SlMlo1 geni üzerinde iki farklı nokta hedef seçilerek 48 bp (baz çifti)'lik bir delesyon oluşturulmuştur. Yeni varyeteler "Tomelo" olarak adlandırılmış ve bu çeşidin Oidium neolycopersici' ye karşı dayanıklı olduğu gösterilmiştir (Nekrasov ve ark., 2017). Ayrıca CRISPR/cas teknolojisi Erysiphe necator (Malnoy ve ark., 2016), Botrytis cinerea (Wang ve ark., 2018a), Blumeria graminis $f$. sp. tritici (Bgt) (Zhang ve ark., 2017) ve Magnaporthe oryzae (Wang ve ark., 2016) gibi patojen funguslara karşı dirençli bitkiler elde edilmesi amacıyla kullanılmıştır. Son zamanlarda CRISPR teknolojisinin biyolojik mücadelede kullanım potansiyeli olan antagonist ya da non-virülent 1rk olan fungusların geliştirilmesine de olanak sağladığı gösterilmiştir (Vicente Muñoz ve ark., 2017; Wang ve ark., 2018b; Vicente Muñoz ve ark., 2019).

\subsection{CRISPR/Cas Teknolojisinin Antibakteriyel Kullanım Alanlart}

Bitki patojeni bakterilerin çoğunluğu çubuk şeklinde olmakla birlikte Streptomyces genusuna ait olanlar ipliksi formdadır. Bitki patojeni bakteriler parazit gibi konukçu bitki üzerinde gelişebilen heterotropik organizmalardır. Bu bakteriler bitki dokusundan doğrudan giriş yapamazlar ve infeksiyon stoma, hidatod gibi doğal açıklıklar veya yaralar aracılığıyla meydana gelmektedir. İnfeksiyon sonrası bitkide nekroz, yanık, kanser, solgunluk, tümör gibi temel simptomlar gelişmektedir (Sobiczewski, 2008). Bakteri hastalıklarına karşı mücadelede bazı antibakteriyel bileşiklerin ve antimikrobiyal peptidlerin kullanımının yanı sıra biyolojik mücadele, kültürel önlemler gibi yöntemler uygulanmaktadır. Ayrıca belirli kimyasallar ile bitkilerde sistemik kazanılmış dayanıklılık (SAR) sisteminin uyarımı bakteriyel kanser hastalığı, bakteriyel solgunluk ve ateş yanıklığı gibi patho-sistemlerde hastalığın önlenmesinde büyük başarı sağlamıştır (Maxson-Stein ve ark., 2002; Pradhanang ve ark., 2005; Sen ve ark., 2015). SAR sisteminden başka, bitkide bulunan diğer bir uyarılmış dayanıklılık sistemi olan ISR'nin uyarılmasıla da $P$. syringae, Xanthomonas oryzae pv. oryzae, $R$. solanacearum gibi farkl1 bakteriyel patojenlere karşı dayanıklılık sağlanmıştır (Kloepper ve ark., 2004).

Son yıllarda bitki ve patojenik bakteri arasındaki interaksiyonda rol oynayan birçok bileşik ortaya konmuştur. Bitki ve patojen bakterilerden elde edilen genomik ve transkriptomik veriler ile birlikte yeni nesil sekanslama teknolojisinin gelişmesi, bitkiler tarafından harekete geçirilen savunma sistemi ve bakteriyel patojenlerin infeksiyon için bitkinin immün sistemini nasıl bertaraf ettiği ile ilgili bilgilerimiz her geçen gün artmaktadır (Jones ve Dangl, 2006). Önemli tarım bitkilerinde R genlerinin tanımlanması ve üstün genotiplere bu genlerin aktarılması fitobakterilerin geniş bir grubunda hastalık yönetim stratejilerine pozitif bir ivme kazandırmıştır. Ancak bakteriler tarafından oluşturulan effektörlerdeki mutasyonel modifikasyonlar sonucu yeni patojen ırklarının oluşması dayanaklılığın kırılmasına neden olduğundan, R genleri ile sağlanan dayanıklılık sabit kalmamaktadır. Bakterilere karşı bitkilerde direnç sağlamak amacıyla yürütülen ıslah çalışmalarında yeni çeşitlere ve üstün genotiplere $\mathrm{R}$ gen gruplarının aktarılması bitki 1slahında yaygın bir strateji haline gelmiştir (Leach ve ark., 2001). Son zamanlarda CRISPR/cas gibi gelişen genom düzenleme teknolojileri bakteri hastalıklarına karşı mücadelede yeni bir çı̆̆ır açmış ve bu teknolojinin bitkilerde bakterilere karşı dayanıklılık sağlamak amacıyla uygulandığı farklı çalışmalar yürütülmüştür. OsSWEET13 geni bitki patojen interaksiyonunda yer alan sukroz taşıyıcı proteini kodlayan bir duyarlılık genidir. Xanthomonas oryzae pv. oryzae konukçu bitkide OsSWEET13 geninin ifadesini uyaran PthXo2 adı verilen effektör bir protein üretir ve bu protein ile OsSWEET13 geninin ifadesi sonucu konukçuda duyarlılık gelişmektedir (Li ve ark., 2012). OsSWEET13 geni bakımından CRISPR/cas9 ile elde edilen null mutantların bakteriyel yanıklığa karşı dayanıklı olduğu ve PthXo2'nin hastalığa duyarlılıkta önemli rol oynadığı gösterilmiştir (Zhou ve ark., 2015). Erwinia amylovora, Rosaceae familyası içerisindeki konukçu türleri etkileyen tahrip edici bitki hastalıklarından olan ateş yanıklığına neden olan bir bakteridir. Ayrica Erwinia amylovora elma, armut ve ayva bitkilerinin yanı sıra hem ticari hem de süs bitkisi olan bitkileri de küresel olarak tehdit etmektedir (Piqué ve ark., 2015). Genetik mühendisliği aracılığıyla ateş yanıklığına dayanıklılığı arttıran birçok aday gen belirlenmiş olmasına rağmen, genetiği değiştirilmiş organizmalar ile ilgili sosyal ve düzenleyici engellerden dolayı Erwinia amylovora 'ya dayanıklı bir çeşit ticari olarak mevcut değildir (Singh ve ark., 2006). Ateş yanıklığına karşı dayanıklılık sağlamak amacıyla CRISPR sistemi kullanılarak ticari bir elma çeşidi olan Golden delicious'un protoplastına cas9 ve farklı sgRNA'lar PEG aracılığıyla aktarılarak DIPM-1, DIPM-2, ve DIPM-4 genlerinde mutasyon oluşturulmuştur. Böylece transgen içermeyen mutant bitkiler elde edilebilme potansiyeli, CRISPR/cas sistemi ile genomu düzenlenen bitkilerin genetiği değiştirilmiş organizmalar (GDO)'ın düzenlemelerinden geçebileceğini göstermiştir (Malnoy ve ark., 2016). Pseudomonas syringae pv. tomato (Pto) domates benek hastalığına neden olan bir bakteri türüdür. Pseudomonas syringae $p v$. tomato (Pto) coronatine (COR) ad 1 verilen bir bileşik üreterek stomal açıklığa olanak sağlayarak bakterilerin yaprakta kolonizasyonuna imkan sağlamaktadır. Coronatine biyoaktif jasmonik asiti (JA) taklit eden bir bileşiktir (Fonseca ve ark., 2009). COR JA yolağını teşvik ederek salisilik asit (SA) bağımlı savunma sistemini baskılamaktadır (Zheng ve ark., 2012). Patojen Pto DC3000'in neden olduğu bakteriyel benek hastalığına karşı dayanıklılığı arttırmak adına SIJAZ2 $\Delta$ jas geninde delesyon oluşturmak için domates bitkisinde CRISPR/cas9 genom düzenleme teknolojisi kullanılmıştır. CRISPR/cas9 ile oluşturulan SIJAZ2 $\Delta$ jas geni bakımından mutant domateslerin yabani tipler ile karşılaştırıldığında domates benek hastalığına karşı dayanıklı olduğu tespit edilmiştir. Ayrıca bu mutant domateslerin Botrytis cinerea'ya karşı da dayanıklı olduğu rapor edilmiştir (Ortigosa ve ark., 2019). Xanthomonas citri subsp. citri (Xcc) (Jia ve ark., 2016), P. syringae, X. gardneri, $X$. perforans (de Toledo Thomazella ve ark., 2016) gibi patojen bakterilere karşı turunçgil ve domateste dayanıklık sağlamada CRISPR/cas genom düzenleme tekniğinin başarılı olduğu gösterilmiştir. 
Tablo 1. CRISPR/Cas Sisteminin Bitki Patojenlerine Dayanıklllık Sağlamada Kullanımı

\begin{tabular}{|c|c|c|c|c|}
\hline Bitki türü & Patojen & Gen editör/ nükleaz & Hedef gen & Litratür \\
\hline Buğday & Blumeria graminis f. sp. tritici & $\begin{array}{l}\text { TALEN ve } \\
\text { CRISPR/cas9 }\end{array}$ & $\begin{array}{l}\text { TaMLO-A1, TaMLO- } \\
B 1 \text { ve TaMLO-D1 }\end{array}$ & Wang ve ark., 2014 \\
\hline Domates & Oidium neolycopersici & CRISPR/cas9 & SlMlo1 & Nekrasov ve ark., 2017 \\
\hline Asma & Erysiphe necator & CRISPR/cas9 & $V v M L O 7$ & Malnoy ve ark., 2016 \\
\hline Buğday & Erysiphe cichoracearum & CRISPR/cas9 & TaEDR1 & Zhang ve ark., 2017 \\
\hline Asma & Botrytis cinerea & CRISPR/cas9 & VvWRKY52 & Wang ve ark.,2018b \\
\hline Pirinç & Xanthomonas oryzae pv. oryzae & CRISPR/cas9 & OsSWEET13 & Zhou ve ark., 2015 \\
\hline Elma & Erwinia amylovora & CRISPR/cas9 & $\begin{array}{l}D I P M-1, D I P M-2 \text { ve DIPM- } \\
4\end{array}$ & Malnoy ve ark., 2016 \\
\hline Domates & Pseudomonas syringae pv. tomato & CRISPR/cas9 & SlJAZ24jas & Ortigosa ve ark., 2019 \\
\hline Turunçgil & Xanthomonas citri subsp. citri & CRISPR/cas9 & $C s L O B 1$ & Jia ve ark., 2016 \\
\hline Turunçgil & Xanthomonas citri subsp. citri & CRISPR/cas9 & $E B E_{P t h A 4}$ & Peng ve ark., 2017 \\
\hline Domates & $\begin{array}{l}\text { Pseudomonas syringae pv. tomato, } \\
\text { Phytophthora capsici, } \\
\text { Xanthomonas spp. }\end{array}$ & CRISPR/cas9 & SlDMR6-1 & $\begin{array}{l}\text { de Toledo Thomazella, } \\
\text { ve ark., } 2016\end{array}$ \\
\hline $\begin{array}{l}\text { N. benthamiana } \\
\text { A. thaliana }\end{array}$ & Beet severe curly top virus & CRISPR/cas9 & $I R, C P, R e p$ & Ji ve ark., 2015 \\
\hline N. benthamiana & Bean yellow dwarf virus & CRISPR/cas9 & LIR, Rep & Baltes ve ark., 2015 \\
\hline N. benthamiana & $\begin{array}{l}\text { Tomato yellow leaf curl virus, } \\
\text { Beet curly top virus, } \\
\text { Merremia mosaic virus }\end{array}$ & CRISPR/cas9 & $C P$, Rep ve IR & Ali ve ark., 2015 \\
\hline Domates & Pseudomonas syringae pv. tomato & CRISPR/cas9 & SlJAZ2ムjas & Ortigosa ve ark., 2019 \\
\hline N. benthamiana & $\begin{array}{l}\text { Cotton Leaf Curl Kokhran Virus, Merremia mosaic } \\
\text { virus, } \\
\text { Tomato yellow leaf curl virus }\end{array}$ & CRISPR/cas9 & $C P$, Rep, ve IR & Ali ve ark., 2016 \\
\hline Arpa & Whaet dwarf virus & CRISPR/cas9 & $C P / M P, L I R, R e p$ & Kis ve ark., 2019 \\
\hline Domates & Tomato yellow leaf curl virus & CRISPR/cas9 & Rep, $C P$ & Tashkandi ve ark., 2018 \\
\hline $\begin{array}{l}\text { A. thaliana, } \\
N . \text { benthamiana }\end{array}$ & Cucumber moasic virus, Tabacco mosaic virus & CRISPR/FnCas9 & ORF1a, ORFCP ve 3'-UTR & Zhang ve ark., 2018 \\
\hline N. benthamiana & Turnip mosaic virus & CRISPR/cas13a & GFP-1, GFP-2, HC-Pro, CP & Aman ve ark., 2018 \\
\hline Patates & Potato virus $Y$ & CRISPR/cas13a & $P 3, C I, N I b$ ve $C P$ & Zhan ve ark., 2019 \\
\hline Hiyar & $\begin{array}{l}\text { Cucumber vein yellowing virus, Zucchini yellow } \\
\text { mosaic virus, Papaya ring spot mosaic virus }-W\end{array}$ & CRISPR/cas9 & eIF4E & $\begin{array}{l}\text { Chandrasekaran ve ark., } \\
2016\end{array}$ \\
\hline A. thaliana & Turnip mosaic virus & CRISPR/cas9 & eIF4E & Pyott et al., 2016 \\
\hline Pirinç & Rice tungro spherical virus & CRISPR/cas9 & eIF4G & Macovei ve ark., 2018 \\
\hline
\end{tabular}

\subsection{Prokaryotik İmmün sistemi CRISPR/Cas İle Virüslere Dayanıklı Bitki Oluşturma}

Biyotik stresler arasında önemli bir yeri olan fitopatojenik virüsler her yıl dünya çapında tarım ürünlerinin veriminde \%1015 oranında bir azalş̧a sebep olmaktadır (Mahy ve van Regenmortel, 2009). Bitki virüslerine karşı konukçu bitki dayanıklılığı arttırılarak bu kaybın bir kısmı önlenebilmektedir. Bitki virüslerinin kontrolü genellikle virüsü taşıyan vektörlere karşı pestisit kullanımına bağlıdır, ancak böylesi bir yaklaşım çevre üzerinde birçok olumsuz etkiye sahiptir (Bragard ve ark., 2013). Virüs hastalıkları ile mücadelede bitkilerde bulunan viral dayanıklılık faktörleri kullanılmaktadır ve bu yöntem ile birçok virüs infeksiyonuna karşı dayanıklılık sağlanmıştır (Ziebell, 2016). Bitkilerde bulunan virüs dayanıklılık genleri kültüre alınan birçok kültür bitkisinin virüse karșı dayanıklı kılınması adına kullanılmıştır (Gómez ve ark., 2009). Ancak dayanıklılık genlerinin kullanılarak virüslere karşı dayanıklılık sağlama çalışmalarının temel dezavantajı virüse karşı stabil dayanıklı bir bitki geliştirmenin uzun zaman ve yüksek maliyet gerektirmesidir (Kang ve ark., 2005a). Son 30 yılda virüs proteinlerinin ya da genomlarının transgenik olarak bitkide ifadesi (ekspresyon) yaklaşımı virüslere dayanıklılık sağlamak adına geniş ölçüde uygulanmıştır (Ding ve Voinnet, 2007). Her ne kadar virüslere karşı dayanıklı bitkilerin kullanımıyla bitki virüsleri ile mücadele edilse de virüslerin çeşitliliği, hızlı evrimi ve çoğunlukla böcek vektörler ile bitkilere taşınmaları, bitki virüs hastalıklarını kontrol etme yaklaşımlarını etkisiz hale getirmektedir (Hanley-Bowdoin ve ark., 2013). Dolayısıyla bitki virüsleri ile mücadelede yeni e-ISSN: 2148-2683 stratejilerin geliştirilmesi büyük önem taşımaktadır. Genom düzenleme alanındaki ilerlemeler tarım ürünlerinde dayanıklılığın arttırılması konusunda da yeni imkânlar sunmaktadır. Son yıllarda popüler olan CRISPR/cas sistemi bitkilerde hem biyotik hem de abiyotik strese karşı dayanıklılık sağlamak amacıyla uygulanmıştır (Arora ve Narula, 2017). Farklı CRISPR/cas stratejileri ökaryotik DNA ya da RNA virüs genomlarının etkili bir şekilde interferansı adına kullanılmıştır (Price ve ark., 2015; Price ve ark., 2016). CRISPR/cas sistemi iki farklı yaklaşım ile bitkilerde virüslere karşı dayanıklılık sağlamak için kullanılmaktadır. İlk yaklaşımda episomal ya da bitki genomuna entegre olmuş viral genom hedef alınarak virüs replikasyonu engellenirken, ikinci yaklaşımda ise virüs enfeksiyonu ve çoğalması için önemli olan konukçu bitki faktörleri CRISPR/cas sistemi ile etkisiz hale getirilerek virüslere karşı bitkide dayanıklılık sağlanmaktadır (Mahas ve Mahfouz, 2018).

Geminivirüsler, 360'dan fazla tür içeren DNA virüsleridirler (Zerbini ve ark., 2017). Sirküler ve tek iplikli DNA genomuna sahip olan geminivirüsler, konukçu bitkinin hücre çekirdeğinde ara form olan çift iplikli DNA (double-stranded DNA; dsDNA) aracıllğıyla replike olurlar (Hanley-Bowdoin ve ark., 2013). Bu ara form genom düzenleme teknolojisinde kullanılan sekans spesifik nükleazlar için uygun bir hedeftir (Yin ve Qui, 2019). CRISPR genom düzenleme tekniği ile şeker pancarı tepe kıvırckklığı hastalığının etmeni olan Beet severe curly top virus (BSCTV)'üne karş1 Nicotiana benthamiana ve Arabidopsis model bitkilerinde dayanıklılık sağlanmıştır (Ji ve ark., 2015). Fasulye sarı cücelik hastalı̆̆ 1 etmeni olan Bean yellow dwarf virus 
(BeYDV)'üne karşı dayanıklı bitkiler elde etmede CRISPR/cas9 genom düzenleme tekniğinin oldukça başarılı olduğu rapor edilmiştir (Baltes ve ark., 2015). Ali ve ark. (2015), Begomovirüs'lere dayanıklılık sağlamak için konukçu hücre içerisinde ifade olan ve replikasyon süresince virüs genomunun parçalanmasını sağlayan CRISPR/cas9 sistemini kullanmışlardır. Çalışmada cas9 endonükleazını stabil olarak ifade eden $N$. benthamiana bitkilerine Tobacco rattle virus (TRV) vektörü aracılığıyla aktarılan farklı bölgeleri hedef alan sgRNA molekülleri (capsid protein (CP), Rep protein RCRII motif ve intergenic region (IR)) dizayn edilmiştir. Bütün sgRNA'ların virüs replikasyonunu ve birikimini engellediği ancak IR bölgesine dizayn edilen sgRNA'ların daha etkili olduğu gösterilmiştir. Aynı CRISPR/cas9 ve sgRNA sisteminde eş zamanlı olarak monopartite Beet curly top virus (BCTV) ve bipartite Merremia mosaic virus (MeMV)'üne karşı tütün bitkisinin dayanıklı olup olmadığ 1 da test edilmiştir. Hem IR hem de CP bölgesine dizayn edilen sgRNA'ların çoklu virüs enfeksiyonlarına karşı dayanıklılık sağladığı rapor edilmiştir (Ali ve ark., 2015). CRISPR/cas genom düzenleme arac1 Wheat dwarf virus (WDV), Tomato yellow leaf curl virus (TYLCV), Cotton leaf curl kokhran virus (CLCuKoV), Merremia mosaic virus (MeMV) gibi farklı virüslere karşı bitkide dayanıklılık oluşturmak amacıyla araştırmacılar tarafindan kullanılmış ve başarılı sonuçlar elde edildiği rapor edilmiştir (Ali ve ark., 2016; Tashkandi ve ark., 2018; Kis ve ark., 2019). Çalışmalar CRISPR/cas9 sistemi ile virüs interferansının birden fazla nesilde kalıtıldığını ve böylece CRISPR/cas9 sisteminin virüse karşı kalıcı dayanıklılık geliştirmede kullanılabileceğini göstermiştir (Tashkandi ve ark., 2018).

CRISPR/cas9 sistemi çift iplikli DNA'yı hedef aldığından dolayı RNA virüslerine karşı CRISPR sistemi ile dayanıklılık oluşturmak genellikle daha zordur. Francisella novicida'dan FnCas9, Leptotrichia shahii'den LshCas13a, Leptotrichia wadei'den LwaCas13a gibi RNA'yı hedef alabilen ve kesen nükleazların araştırılması ve karakterizasyonu CRISPR sisteminin viral RNA interferansında etkin bir şekilde kullanılabileceğini göstermiştir (Sampson ve ark., 2013; Abudayyeh ve ark., 2016; Abudayyeh ve ark., 2017). Birçok bitki türünü enfekte eden pozitif sense RNA virüslerinden olan Cucumber moasic virus ve Tabacco mosaic virüs'üne karş1 Arabidopsis ve $N$. benthamiana bitkilerinde direnç sağlamak için CRISPR/FnCas9 sisteminin etkinliği araştırılmıştır. F. novicida CRISPR/cas9 sistemin hem geçici olarak hem de stabil olarak ifade edildiği bitkiler CMV ve TMV ile inoküle edildikten sonra, FnCas9'un RNA virüslerine karşı interferans etkinliği değerlendirilmiştir. Transgenik bitkiler kontrol bitkilerle karşılaştırıldığında, transgenik bitkilerde virüsün çoğalmasınının \%40-80 oranında engellendiği, hastalık semptomunun azaldığı ve FnCas9-sgRNA ile sağlanan virüs direncinin bitkilere kalıtsal olarak aktarıldığı gösterilmiştir (Zhang ve ark., 2018).

CRISPR/cas13a bir RNA dizisi tarafından yönlendirilen son zamanlarda karakterize edilmiş yeni bir genom düzenleme aracıdır (Abudayyeh ve ark., 2016; Liu ve ark., 2017). Potyvirüsler tarım bakımından önemli olan birçok bitki türünde ekonomik olarak ciddi kayıplara neden olmaktadırlar (Gibss ve Ohshima, 2010). Turnip mosaic virus (TuMV), Potyvirus cinsine ait bir virüs türü olup, özellikle Brassicae familyasındaki bitkilerde ciddi ekonomik kayıplara yol açmaktadır. Geniş konak aralığına sahip olması ve en az yaklaşık 90 farklı afid türü ile nonpersistent olarak taşınması TuMV'nin kontrolünü kısıtlayan önemli faktörlerdendir (Walsh ve Jenner, 2002). Aman ve ark.
(2018), TuMV'üne ait RNA genomunun, RNA-guided ribonükleaz Cas13a ile manipüle edilebildiğini göstermiştir. TuMV-GPF genomunu ifade eden transgenik tütün bitkileri oluşturulmuş ve RNA interferansı için TuMV genomunda 4 farklı bölge (GFP-1, GFP-2, HC-Pro ve CP) sgRNA'yı dizayn etmek için hedef olarak seçilmiştir. Hc-Pro ve GFP2 bölgelerini hedef alan CRISPR/cas13a RNA düzenleme sisteminin diğer iki bölge ile karşılaştırıldığında virüs interferansında daha etkili olduğu gösterilmiştir. CRISPR/cas13a RNA düzenleme sistemi Potyvirus üyesi olan Potato virus Y'ye karşı patateste dayanıklılık oluşturmak için uygulanmıştır (Zhan ve ark., 2019). 3 farklı PVY 1rkının $\left(\mathrm{PVY}^{\mathrm{O}}, \mathrm{PVY}^{\mathrm{N}}\right.$ ve recombinant $\mathrm{PVY}^{\mathrm{N}: \mathrm{O}}$ ) korunmuş kodlayan bölgelerine dizayn edilen sgRNA'lar ile oluşturulan CRISPR/cas 13a sisteminin etkinliği patates bitkisinde viral direnç oluşturmak için araştırılmıştır. sgRNA'lar PVY genomuna ait P3, $\mathrm{CI}$, NIb ve CP kodlayan gen bölgelerinin korunmuş kısımlarına göre dizayn edilmiştir. CRISPR/cas13a sistemini yüksek seviyede ifade eden transgenik patates bitkileri trangenik olmayan kontrol bitkiler ile karşılaştırıldığında PVY hastalık semptomu göstermemiştir. ELISA ve qRT-PCR transgenik bitkilerde PVY ile inoküle edildikten 20 ve 25 gün sonra PVY'nin birikiminin azaldığını ortaya koymuştur. Sonuçlar CRISPR/cas13a sisteminin PVY'nin farklı ırklarında eş zamanlı olarak patates bitkisinde direnç sağlamada etkili olduğunu ve bu sistemin PVY'nin kontrolünde kullanılabileceğini göstermiştir (Zhan ve ark., 2019).

Virüsler kendi virionlarında ribozomdan yoksun olduklarından dolayı viral protein sentezi konak bitkinin translasyon sistemine bağlı olarak gerçekleşmektedir. Bitkilerde eIF4E ve onun izoformları multi-komponent translasyon kompleksinde yer alan translasyon başlama faktörleridir. Dolayısıyla translasyon başlama faktörleri viral proteinlerin translayonu için de gereklidir (Sanfaçon, 2015). Chandrasekaran ve ark. (2016), CRISPR/cas9 ile konakçı duyarlılık geni eIF4E'nin bağımsız olarak iki farklı bölgesinde mutasyon oluşturarak çoklu Potyvirüse karşı dirençli transgenik olmayan hıyar bitkisi geliştirmişlerdir. Non-transgenik Cucumis eif4e mutant bitkiler 3 nesil geriye melezleme ile CRISPR/cas9'un segregasyonundan faydalanılarak oluşturulmuştur. Mutasyon bakımından homozigot alleleri taşıyan T3 bitkilerinin heterezigot ve mutant olmayanlar ile karşılaştırıldığında Cucumber vein yellowing virus, Zucchini yellow mosaic virus ve Papaya ring spot mosaic virus-W'e karşı dayanıklı olduğu ortaya konmuştur.

Benzer bir yaklaşım cassava (manyok) bitkisinde de uygulanmıştır. Cassava kahverengi çizgi hastalığı, cassava bitkisinde verimi etkileyen önemli bir hastalık olup, hastalığa iki farklı pozitif sense RNA virüsü Cassava brown streak virus (CBSV) ve Ugandan cassava brown streak virus (UCBSV) neden olmaktadır (Revers ve Garcia, 2015). Viral VPg proteini ve konak ökaryotik translasyon başlama faktör 4E izoformları arasındaki interaksiyon hastalık oluşumunda önemli rol oynamaktadır (Kang ve ark., 2005b; Yeam ve ark., 2007). Gomez ve ark. (2019), CRISPR/cas9 aracılığıyla novel cap-binding protein-1 (nCBP-1) ve nCBP-2 proteini bakımından mutant cassava 60444 çeşidi geliştirmişlerdir. Mutant bitkilerin Cassava kahverengi çizgi hastalığına karşı dayanıklı olduğu ve virüs titresinin yabani tipkontrol bitkiler ile karşılaştırıldığında oldukça az olduğu ortaya konmuştur. Arabidopsis thaliana genomunda yer alan translasyon başlama faktöründe CRISPR/cas9 sistemi ile oluşturulan dizi yönlendirilmiş mutasyonların TuMV'ye karşı dirençte etkinliği araştırılmıştır. Cas9 ve sgRNA ile oluşturulan transgenik mutant bitkiler kendine tozlanarak T2 bitkileri elde edilmiştir. Homozigot mutant bitkiler kendilenerek transgen içermeyen eIF4E geni 
bakımından mutant T3 bitkileri elde edilmiştir. Elde edilen nontransgenik Arabidopsis bitkilerinin TuMV'e karşı direnç gösterdiği ortaya konulmuştur (Pyott ve ark., 2016). Macovei ve ark. (2018), CRISPR/cas9 teknolojisini kullanarak eIF4G allellerinin mutagenezi ile Rice tungro spherical virus (RTSV)'üne karşı çeltik bitkisinde direnç oluşturmuşlardır. Elde edilen T2 bitkilerinden bazılarının Cas9'u içermediği ve RTSV'ye karşı dirençli olduğu gösterilmiştir.

\section{Sonuç}

Yüz yıllardır insan-oğlu spontan mutasyonları ve rekombinasyon yoluyla oluşan genetik çeşitlilikten faydalanarak farklı amaçlar doğrultusunda bitkilerde seleksiyon yapmışlardır. Geleneksel islah yaklaşımı bugün kullanmakta olduğumuz bitki çeşitlerini ortaya koymuştur. Her ne kadar moleküler yaklaşımların kullanılmasıyla geleneksel ıslah yönteminde ıslah süresi kısalsa da, ıslah sürecinin hala uzun süre gerektirmesi, bazen istenilmeyen sonuçların ortaya çıkması, yoğun iş gücü gerektirmesi ve transgenik ürünlere tüketicinin yaklaşımı gibi sorunlar patojenlere karşı dayanıklı bitki geliştirmede birer handikap olarak kalmaktadır. Son zamanlarda ortaya çıkan genom düzenleme teknolojilerinden özellikle CRISPR/cas sistemi bu handikapları ortadan kaldırmasıyla bitkilerin iyileştirilmesi amacıyla bitki ıslahında kullanılan etkili ve spesifik bir yöntemlerdendir. Ayrıca genomda birden fazla genin eş zamanlı olarak hedef alınması, istenilen bölgede delesyon ya da insersiyona olanak sağlaması, ilk nesilde sonraki nesillere aktarılabilen heterozigot ya da homozigot mutasyonlar oluşturması ve metabolik yolakların manipüle edilmesine olanak sağlaması gibi avantajlar CRISPR sistemini diğer genom düzenleme tekniklerine kıyasla daha fazla uygulama alanına sahip kılmaktadır (Akbudak ve Kontbay, 2017). CRISPR/cas sisteminin hastalığa neden olan patojenlere karşı bitkileri dayanıklı/toleranslı kılmada ve patojenler ile mücadelede etkili bir araç olduğu birçok yayında ele alınmıştır. Genom düzenleme hem moleküler bitkipatojen interaksiyonları hakkında bilgimizin artması hem de hastalıklara karşı dayanıklı bitki ıslahı bakımından eşsiz firsatlar sunan bir yaklaşımdır. Dolayısıyla bu teknolojinin gelecekte bitki 1slah süresini hızlandırması ve sürdürülebilir bir tarıma katkı sağlaması amacıyla farklı patojenlere karşı dayanıklı bitki elde edilerek yaygın olarak kullanılacağı öngörülmektedir. Ancak genom düzenleme yoluyla arzu edilen özellik bakımından genomu düzenlenmiş bitkilerin halk sağlığı ve genetiği değiştirilmiş organizmalar (GDO) açısından yasaları belirleyen kurumlar tarafından kabul görüp görmeyeceği ile ilgili tartışmalar doğmaktadır. $\mathrm{Bu}$ tartışmanın iki tarafı vardır. Bir grup CRISPR/cas sistemi gibi yeni bitki 1slah teknolojilerinin, geleneksel 1slah ile üretilen bitkilerle bu teknolojiler ile üretilen bitkilerin benzer olduğu iddiasıyla GDO düzenlemelerinin haricinde tutulması gerektiğini öne sürmektedirler. Karşıt grup ise bu teknolojiler ile üretilen bitkilerin GDO düzenlemeleri kapsamında olması gerektiğini savunmaktadır. Gelecekte küresel iklim değişikliğinin boyutu dikkate alındığında daha esnek düzenlemelerin söz konusu olabileceği ve CRISPR/ cas sistemi ile bitki 1slahı gibi daha yenilikçi besin üretim tekniklerinin kullamının yaygın hale geleceğide kaçınılmaz görülmektedir.

\section{Kaynakça}

Abudayyeh, O. O., Gootenberg, J. S., Konermann, S., Joung, J., Slaymaker, I. M., Cox, D. B., ... \& Severinov, K. (2016). C2c2 is a single-component programmable RNA-guided RNAtargeting CRISPR effector. Science, 353(6299), aaf5573.

Abudayyeh, O. O., Gootenberg, J. S., Essletzbichler, P., Han, S., Joung, J., Belanto, J. J., ... \& Lander, E. S. (2017). RNA targeting with CRISPR-Cas13. Nature, 550(7675), 280-284.

AKBUDAK, M. A., \& Kontbay, K. (2017). Yeni Nesil Genom Düzenleme Teknikleri: ZFN, TALEN, CRISPR'lar ve Bitkilerde Kullanımı. Tarla Bitkileri Merkez Araştırma Enstitüsü Dergisi, 26(1), 111-126.

Ali, Z., Abulfaraj, A., Idris, A., Ali, S., Tashkandi, M., \& Mahfouz, M. M. (2015). CRISPR/Cas9-mediated viral interference in plants. Genome biology, 16(1), 238.

Ali, Z., Ali, S., Tashkandi, M., Zaidi, S. S. E. A., \& Mahfouz, M. M. (2016). CRISPR/Cas9-mediated immunity to geminiviruses: differential interference and evasion. Scientific reports, 6(1), 1-13.

Aman, R., Ali, Z., Butt, H., Mahas, A., Aljedaani, F., Khan, M. Z., ... \& Mahfouz, M. (2018). RNA virus interference via CRISPR/Cas13a system in plants. Genome biology, 19(1), 19.

Arora, L., \& Narula, A. (2017). Gene editing and crop improvement using CRISPR-Cas9 system. Frontiers in plant science, 8, 1932.

Ateş Sönmezoğlu, Ö., Yıldırım, A., Türk, Ü., \& Yanar, Y. (2019). Bazı Yerel Makarnalık Buğday Çeşitlerinde Küllemeye (Blumeria graminis f. sp. tritici) Karşı Dayanıklılığın Belirlenmesi. Avrupa Bilim ve Teknoloji Dergisi, (17), 944950.

Baltes, N. J., Hummel, A. W., Konecna, E., Cegan, R., Bruns, A. N., Bisaro, D. M., \& Voytas, D. F. (2015). Conferring resistance to geminiviruses with the CRISPR-Cas prokaryotic immune system. Nature Plants, 1(10), 1-4.

Barrangou, R., Fremaux, C., Deveau, H., Richards, M., Boyaval, P., Moineau, S., ... \& Horvath, P. (2007). CRISPR provides acquired resistance against viruses in prokaryotes. Science, 315(5819), 1709-1712.

Bayat, H., Naderi, F., Khan, A. H., Memarnejadian, A., \& Rahimpour, A. (2018). The impact of crispr-cas system on antiviral therapy. Advanced Pharmaceutical Bulletin, 8(4), 591.

Borrelli, V. M., Brambilla, V., Rogowsky, P., Marocco, A., \& Lanubile, A. (2018). The enhancement of plant disease resistance using CRISPR/Cas9 technology. Frontiers in plant science, 9, 1245.

Bortesi, L., \& Fischer, R. (2015). The CRISPR/Cas9 system for plant genome editing and beyond. Biotechnology advances, 33(1), 41-52.

Bragard, C., Caciagli, P., Lemaire, O., Lopez-Moya, J. J., MacFarlane, S., Peters, D., ... \& Torrance, L. (2013). Status and prospects of plant virus control through interference with vector transmission. Annual review of phytopathology, 51, 177-201.

Chandrasekaran, J., Brumin, M., Wolf, D., Leibman, D., Klap, C., Pearlsman, M., ... \& Gal-On, A. (2016). Development of broad virus resistance in non-transgenic cucumber using CRISPR/Cas9 technology. Molecular plant pathology, 17(7), 1140-1153.

Christopoulou, M., Wo, S. R. C., Kozik, A., McHale, L. K., Truco, M. J., Wroblewski, T., \& Michelmore, R. W. (2015). Genome-wide architecture of disease resistance genes in lettuce. G3: Genes, Genomes, Genetics, 5(12), 2655-2669.

Consonni, C., Humphry, M. E., Hartmann, H. A., Livaja, M., Durner, J., Westphal, L., ... \& Somerville, S. C. (2006). 
Conserved requirement for a plant host cell protein in powdery mildew pathogenesis. Nature genetics, 38(6), 716720.

Dai, W. J., Zhu, L. Y., Yan, Z. Y., Xu, Y., Wang, Q. L., \& Lu, X. J. (2016). CRISPR-Cas9 for in vivo gene therapy: Promise and hurdles. Molecular Therapy-Nucleic Acids, 5, e349.

De Toledo Thomazella, D. P., Brail, Q., Dahlbeck, D., \& Staskawicz, B. (2016). CRISPR-Cas9 mediated mutagenesis of a DMR6 ortholog in tomato confers broad-spectrum disease resistance. BioRxiv, 064824.

Ding, S. W., \& Voinnet, O. (2007). Antiviral immunity directed by small RNAs. Cell, 130(3), 413-426.

Doehlemann, G., Ökmen, B., Zhu, W., Sharon, A. (2017). Plant Pathogenic Fungi. The Fungal Kingdom: 703-726, Washington-American.

Dunn, D. A., \& Pinkert, C. A. (2014). Gene editing. In Transgenic Animal Technology (pp. 229-248). Elsevier.

FAO, (2017). The Future of Food and Agriculture - Trends and Challenges. Rome, Italy.

Fonseca, S., Chico, J. M., \& Solano, R. (2009). The jasmonate pathway: the ligand, the receptor and the core signalling module. Current opinion in plant biology, 12(5), 539-547.

Gao, J., Wang, G., Ma, S., Xie, X., Wu, X., Zhang, X., ... \& Xia, Q. (2015). CRISPR/Cas9-mediated targeted mutagenesis in Nicotiana tabacum. Plant molecular biology, 87(1-2), 99110.

Gibbs, A., \& Ohshima, K. (2010). Potyviruses and the digital revolution. Annual review of phytopathology, 48, 205-223.

Gómez, P., Rodríguez-Hernández, A. M., Moury, B., \& Aranda, M. A. (2009). Genetic resistance for the sustainable control of plant virus diseases: breeding, mechanisms and durability. European journal of plant pathology, 125(1), 122.

Gomez, M. A., Lin, Z. D., Moll, T., Chauhan, R. D., Hayden, L., Renninger, K., .. \& Bart, R. S. (2019). Simultaneous CRISPR/Cas9-mediated editing of cassava eIF 4E isoforms nCBP-1 and nCBP-2 reduces cassava brown streak disease symptom severity and incidence. Plant biotechnology journal, 17(2), 421-434.

Griggs, D., Smith, M. S., Rockström, J., Öhman, M. C., Gaffney, O., Glaser, G., ... \& Shyamsundar, P. (2014). An integrated framework for sustainable development goals. Ecology and Society, 19(4).

Hanley-Bowdoin, L., Bejarano, E. R., Robertson, D., \& Mansoor, S. (2013). Geminiviruses: masters at redirecting and reprogramming plant processes. Nature Reviews Microbiology, 11(11), 777-788.

Herrera-Estrella, L., Depicker, A., Van Montagu, M., \& Schell, J. (1983). Expression of chimaeric genes transferred into plant cells using a Ti-plasmid-derived vector. Nature, 303(5914), 209-213.

Horvath, P., \& Barrangou, R. (2010). CRISPR/Cas, the immune system of bacteria and archaea. Science, 327(5962), 167-170.

Ishino, Y., Shinagawa, H., Makino, K., Amemura, M., \& Nakata, A. (1987). Nucleotide sequence of the iap gene, responsible for alkaline phosphatase isozyme conversion in Escherichia coli, and identification of the gene product. Journal of bacteriology, 169(12), 5429-5433.

Jansen, R., Embden, J. D. V., Gaastra, W., \& Schouls, L. M. (2002). Identification of genes that are associated with DNA repeats in prokaryotes. Molecular microbiology, 43(6), 15651575.
Javed, M. R., Sadaf, M., Ahmed, T., Jamil, A., Nawaz, M., Abbas, H., \& Ijaz, A. (2018). CRISPR-Cas system: history and prospects as a genome editing tool in microorganisms. Current microbiology, 75(12), 1675-1683.

Ji, X., Zhang, H., Zhang, Y., Wang, Y., \& Gao, C. (2015). Establishing a CRISPR-Cas-like immune system conferring DNA virus resistance in plants. Nature Plants, 1(10), 1-4.

Jia, H., Orbovic, V., Jones, J. B., \& Wang, N. (2016). Modification of the PthA4 effector binding elements in Type I Cs LOB 1 promoter using Cas9/sg RNA to produce transgenic Duncan grapefruit alleviating Xcc $\Delta$ pthA4: dCs LOB 1.3 infection. Plant biotechnology journal, 14(5), 1291-1301.

Jiang, W., Zhou, H., Bi, H., Fromm, M., Yang, B., \& Weeks, D. P. (2013). Demonstration of CRISPR/Cas9/sgRNA-mediated targeted gene modification in Arabidopsis, tobacco, sorghum and rice. Nucleic acids research, 41(20), e188-e188.

Jinek, M., Chylinski, K., Fonfara, I., Hauer, M., Doudna, J. A., \& Charpentier, E. (2012). A programmable dual-RNA-guided DNA endonuclease in adaptive bacterial immunity. science, 337(6096), 816-821.

Jones, J. D., \& Dangl, J. L. (2006). The plant immune system. nature, 444(7117), 323-329.

Karimi, Z., Ahmadi, A., Najafi, A., \& Ranjbar, R. (2018). Bacterial CRISPR regions: general features and their potential for epidemiological molecular typing studies. The open microbiology journal, 12, 59.

Kang, B. C., Yeam, I., \& Jahn, M. M. (2005a). Genetics of plant virus resistance. Annu. Rev. Phytopathol., 43, 581-621.

Kang, B. C., Yeam, I., Frantz, J. D., Murphy, J. F., \& Jahn, M. M. (2005b). The pvr1 locus in Capsicum encodes a translation initiation factor eIF4E that interacts with Tobacco etch virus VPg. The Plant Journal, 42(3), 392-405.

Kim, H., \& Kim, J. S. (2014). A guide to genome engineering with programmable nucleases. Nature Reviews Genetics, 15(5), 321-334.

Kis, A., Hamar, É., Tholt, G., Bán, R., \& Havelda, Z. (2019). Creating highly efficient resistance against wheat dwarf virus in barley by employing CRISPR/Cas9 system. Plant biotechnology journal, 17(6), 1004.

Klein, T. M., Fromm, M., Weissinger, A., Tomes, D., Schaaf, S., Sletten, M., \& Sanford, J. C. (1988). Transfer of foreign genes into intact maize cells with high-velocity microprojectiles. Proceedings of the National Academy of Sciences, 85(12), 4305-4309.

Kloepper, J. W., Ryu, C. M., \& Zhang, S. (2004). Induced systemic resistance and promotion of plant growth by Bacillus spp. Phytopathology, 94(11), 1259-1266.

Lau, C. H. (2018). Applications of crispr-cas in bioengineering, biotechnology, and translational research. The CRISPR journal, 1(6), 379-404.

Leach, J. E., Vera Cruz, C. M., Bai, J., \& Leung, H. (2001). Pathogen fitness penalty as a predictor of durability of disease resistance genes. Annual review of phytopathology, 39(1), 187-224.

Li, T., Liu, B., Spalding, M. H., Weeks, D. P., \& Yang, B. (2012). High-efficiency TALEN-based gene editing produces disease-resistant rice. Nature biotechnology, 30(5), 390.

Liu, L., Li, X., Ma, J., Li, Z., You, L., Wang, J., ... \& Wang, Y. (2017). The molecular architecture for RNA-guided RNA cleavage by Cas13a. Cell, 170(4), 714-726.

Lyngkjær, M., Newton, A., Atzema, J., \& Baker, S. (2000). The barley mlo-gene: an important powdery mildew resistance source. 
Macovei, A., Sevilla, N. R., Cantos, C., Jonson, G. B., SlametLoedin, I., Čermák, T., ... \& Chadha-Mohanty, P. (2018). Novel alleles of rice eIF4G generated by CRISPR/Cas9targeted mutagenesis confer resistance to Rice tungro spherical virus. Plant biotechnology journal, 16(11), 19181927.

Mahas, A., \& Mahfouz, M. (2018). Engineering virus resistance via CRISPR-Cas systems. Current opinion in virology, 32, 18.

Mahy, B. W. J., van Regenmortel, M. H. V. (2009). Desk Encyclopedia of Plant and Fungal Virology. Cambridge, MA: Academic Press.

Maxson-Stein, K., He, S. Y., Hammerschmidt, R., \& Jones, A. L. (2002). Effect of treating apple trees with acibenzolar-Smethyl on fire blight and expression of pathogenesis-related protein genes. Plant disease, 86(7), 785-790.

Malnoy, M., Viola, R., Jung, M. H., Koo, O. J., Kim, S., Kim, J. S., ... \& Nagamangala Kanchiswamy, C. (2016). DNA-free genetically edited grapevine and apple protoplast using CRISPR/Cas9 ribonucleoproteins. Frontiers in plant science, 7, 1904.

Miklis, M., Consonni, C., Bhat, R. A., Lipka, V., Schulze-Lefert, P., \& Panstruga, R. (2007). Barley MLO modulates actindependent and actin-independent antifungal defense pathways at the cell periphery. Plant Physiology, 144(2), 1132-1143.

Mojica, F. J., García-Martínez, J., \& Soria, E. (2005). Intervening sequences of regularly spaced prokaryotic repeats derive from foreign genetic elements. Journal of molecular evolution, 60(2), 174-182.

Nekrasov, V., Wang, C., Win, J., Lanz, C., Weigel, D., \& Kamoun, S. (2017). Rapid generation of a transgene-free powdery mildew resistant tomato by genome deletion. Scientific reports, 7(1), 1-6.

Ortigosa, A., Gimenez-Ibanez, S., Leonhardt, N., \& Solano, R. (2019). Design of a bacterial speck resistant tomato by CRISPR/Cas9-mediated editing of Sl JAZ 2. Plant biotechnology journal, 17(3), 665-673.

Osakabe, Y., Watanabe, T., Sugano, S. S., Ueta, R., Ishihara, R., Shinozaki, K., \& Osakabe, K. (2016). Optimization of CRISPR/Cas9 genome editing to modify abiotic stress responses in plants. Scientific reports, 6, 26685.

Pacher, M., \& Puchta, H. (2017). From classical mutagenesis to nuclease-based breeding-directing natural DNA repair for a natural end-product. The Plant Journal, 90(4), 819-833.

Peng, A., Chen, S., Lei, T., Xu, L., He, Y., Wu, L., ... \& Zou, X. (2017). Engineering canker-resistant plants through CRISPR/Cas9-targeted editing of the susceptibility gene Cs LOB 1 promoter in citrus. Plant biotechnology journal, 15(12), 1509-1519.

Piffanelli, P., Ramsay, L., Waugh, R., Benabdelmouna, A., D'Hont, A., Hollricher, K., ... \& Panstruga, R. (2004). A barley cultivation-associated polymorphism conveys resistance to powdery mildew. Nature, 430(7002), 887-891.

Piqué, N., Miñana-Galbis, D., Merino, S., \& Tomás, J. M. (2015). Virulence factors of Erwinia amylovora: a review. International journal of molecular sciences, 16(6), 12836-12854

Pradhanang, P. M., Ji, P., Momol, M. T., Olson, S. M., Mayfield, J. L., \& Jones, J. B. (2005). Application of acibenzolar-Smethyl enhances host resistance in tomato against Ralstonia solanacearum. Plant disease, 89(9), 989-993.
Price, A. A., Sampson, T. R., Ratner, H. K., Grakoui, A., \& Weiss, D. S. (2015). Cas9-mediated targeting of viral RNA in eukaryotic cells. Proceedings of the National Academy of Sciences, 112(19), 6164-6169.

Price, A. A., Grakoui, A., \& Weiss, D. S. (2016). Harnessing the prokaryotic adaptive immune system as a eukaryotic antiviral defense. Trends in microbiology, 24(4), 294-306.

Puchta, H. (2005). The repair of double-strand breaks in plants: mechanisms and consequences for genome evolution. Journal of experimental botany, 56(409), 1-14.

Puchta, H., Dujon, B., \& Hohn, B. (1993). Homologous recombination in plant cells is enhanced by in vivo induction of double strand breaks into DNA by a site-specific endonuclease. Nucleic acids research, 21(22), 5034-5040.

Puchta, H., Dujon, B., \& Hohn, B. (1996). Two different but related mechanisms are used in plants for the repair of genomic double-strand breaks by homologous recombination. Proceedings of the National Academy of Sciences, 93(10), 5055-5060.

Pyott, D. E., Sheehan, E., \& Molnar, A. (2016). Engineering of CRISPR/Cas9-mediated potyvirus resistance in transgenefree Arabidopsis plants. Molecular plant pathology, 17(8), 1276-1288.

Revers, F., \& García, J. A. (2015). Molecular biology of potyviruses. In Advances in virus research (Vol. 92, pp. 101199). Academic Press.

Salomon, S., \& Puchta, H. (1998). Capture of genomic and TDNA sequences during double-strand break repair in somatic plant cells. The EMBO journal, 17(20), 6086-6095.

Sampson, T. R., Saroj, S. D., Llewellyn, A. C., Tzeng, Y. L., \& Weiss, D. S. (2013). A CRISPR/Cas system mediates bacterial innate immune evasion and virulence. Nature, 497(7448), 254-257.

Sander, J. D., \& Joung, J. K. (2014). CRISPR-Cas systems for editing, regulating and targeting genomes. Nature biotechnology, 32(4), 347-355.

Sanfaçon, H. (2015). Plant translation factors and virus resistance. Viruses, 7(7), 3392-3419.

Scheben, A., \& Edwards, D. (2018). Towards a more predictable plant breeding pipeline with CRISPR/Cas-induced allelic series to optimize quantitative and qualitative traits. Current opinion in plant biology, 45, 218-225.

Sen, Y., van der Wolf, J., Visser, R. G., \& van Heusden, S. (2015). Bacterial canker of tomato: current knowledge of detection, management, resistance, and interactions. Plant Disease, 99(1), 4-13.

Shi, J., \& Lai, J. (2015). Patterns of genomic changes with crop domestication and breeding. Current opinion in plant biology, 24, 47-53.

Singh, O. V., Ghai, S., Paul, D., \& Jain, R. K. (2006). Genetically modified crops: success, safety assessment, and public concern. Applied microbiology and biotechnology, 71(5), 598-607.

Sobiczewski, P. (2008). Bacterial diseases of plants: Epidemiology, diagnostics and control. Zemdirbyste, 95, 151-157.

Svitashev, S., Young, J. K., Schwartz, C., Gao, H., Falco, S. C., \& Cigan, A. M. (2015). Targeted mutagenesis, precise gene editing, and site-specific gene insertion in maize using Cas9 and guide RNA. Plant physiology, 169(2), 931-945.

Tashkandi, M., Ali, Z., Aljedaani, F., Shami, A., \& Mahfouz, M. M. (2018). Engineering resistance against Tomato yellow leaf 
curl virus via the CRISPR/Cas9 system in tomato. Plant signaling \& behavior, 13(10), e1525996.

Tilman, D., Balzer, C., Hill, J., \& Befort, B. L. (2011). Global food demand and the sustainable intensification of agriculture. Proceedings of the national academy of sciences, 108(50), 20260-20264.

Vicente Muñoz, I., Sarrocco, S., Vannacci, G. (2017). CRISPRCAS for the Genome Editing of Two Trichoderma spp. Beneficial Isolates. Journal Plant Pathology, 99: S63.

Vicente Muñoz, I., Sarrocco, S., Malfatti, L., Baroncelli, R., Vannacci, G. (2019). CRISPR-Cas for Fungal Genome Editing: A New Tool for the Management of Plant Diseases. Frontiers in Plant Science, 10: 135.

Walsh, J. A., \& Jenner, C. E. (2002). Turnip mosaic virus and the quest for durable resistance. Molecular plant pathology, 3(5), 289-300.

Wang, H., Yang, H., Shivalila, C. S., Dawlaty, M. M., Cheng, A. W., Zhang, F., \& Jaenisch, R. (2013). One-step generation of mice carrying mutations in multiple genes by CRISPR/Casmediated genome engineering. Cell, 153(4), 910-918.

Wang, X., Tu, M., Wang, D., Liu, J., Li, Y., Li, Z., ... \& Wang, X. (2018a). CRISPR/Cas9-mediated efficient targeted mutagenesis in grape in the first generation. Plant biotechnology journal, 16(4), 844-855.

Wang, Q., Cobine, P. A., \& Coleman, J. J. (2018b). Efficient genome editing in Fusarium oxysporum based on CRISPR/Cas9 ribonucleoprotein complexes. Fungal Genetics and Biology, 117, 21-29.

Wang, Y., Cheng, X., Shan, Q., Zhang, Y., Liu, J., Gao, C., \& Qiu, J. L. (2014). Simultaneous editing of three homoeoalleles in hexaploid bread wheat confers heritable resistance to powdery mildew. Nature biotechnology, 32(9), 947-951.

Wang, F., Wang, C., Liu, P., Lei, C., Hao, W., Gao, Y., ... \& Zhao, K. (2016). Enhanced rice blast resistance by CRISPR/Cas9targeted mutagenesis of the ERF transcription factor gene OsERF922. PloS one, 11(4), e0154027.

Watson, A., Ghosh, S., Williams, M. J., Cuddy, W. S., Simmonds, J., Rey, M. D., ... \& Adamski, N. M. (2018). Speed breeding is a powerful tool to accelerate crop research and breeding. Nature plants, 4(1), 23-29.

Yeam, I., Cavatorta, J. R., Ripoll, D. R., Kang, B. C., \& Jahn, M. M. (2007). Functional dissection of naturally occurring amino acid substitutions in eIF4E that confers recessive potyvirus resistance in plants. The Plant Cell, 19(9), 2913-2928.

Yin, K., \& Qiu, J. L. (2019). Genome editing for plant disease resistance: applications and perspectives. Philosophical Transactions of the Royal Society B, 374(1767), 20180322.
Zaidi, S. S. E. A., Tashkandi, M., Mansoor, S., \& Mahfouz, M. M. (2016). Engineering plant immunity: using CRISPR/Cas9 to generate virus resistance. Frontiers in plant science, 7, 1673.

Zerbini, F. M., Briddon, R. W., Idris, A., Martin, D. P., Moriones, E., Navas-Castillo, J., ... \& Consortium, I. R. (2017). ICTV virus taxonomy profile: Geminiviridae. The Journal of general virology, 98(2), 131.

Zhan, X., Zhang, F., Zhong, Z., Chen, R., Wang, Y., Chang, L., ... \& Zhang, J. (2019). Generation of virus-resistant potato plants by RNA genome targeting. Plant biotechnology journal, 17(9), 1814-1822.

Zhang, H., Zhang, J., Wei, P., Zhang, B., Gou, F., Feng, Z., ... \& Zhu, J. K. (2014). The CRISPR/C as9 system produces specific and homozygous targeted gene editing in rice in one generation. Plant biotechnology journal, 12(6), 797-807.

Zhang, Y., Bai, Y., Wu, G., Zou, S., Chen, Y., Gao, C., \& Tang, D. (2017). Simultaneous modification of three homoeologs of Ta EDR 1 by genome editing enhances powdery mildew resistance in wheat. The Plant Journal, 91(4), 714-724.

Zhang, T., Zheng, Q., Yi, X., An, H., Zhao, Y., Ma, S., \& Zhou, G. (2018). Establishing RNA virus resistance in plants by harnessing CRISPR immune system. Plant biotechnology journal, 16(8), 1415-1423.

Zheng, X. Y., Spivey, N. W., Zeng, W., Liu, P. P., Fu, Z. Q., Klessig, D. F., ... \& Dong, X. (2012). Coronatine promotes Pseudomonas syringae virulence in plants by activating a signaling cascade that inhibits salicylic acid accumulation. Cell host \& microbe, 11(6), 587-596.

Zheng, Z., Appiano, M., Pavan, S., Bracuto, V., Ricciardi, L., Visser, R.G.F., Wolters, A.M.A., Bai, Y. (2016). GenomeWide Study of the Tomato SIMLO Gene Family and Its Functional Characterization in Response to the Powdery Mildew Fungus Oidium neolycopersici. Frontiers in Plant Science, 7: 380 .

Zhou, J., Peng, Z., Long, J., Sosso, D., Liu, B., Eom, J. S., ... \& White, F. F. (2015). Gene targeting by the TAL effector PthXo2 reveals cryptic resistance gene for bacterial blight of rice. The Plant Journal, 82(4), 632-643.

Ziebell, H. (2016). Plant defence and viral interference. In PlantVirus Interactions (pp. 123-159). Springer, Cham. 